Supporting Information

\title{
The Interfacial Behavior between Biochar and Soil Minerals and Its Effect on Biochar Stability
}

\author{
Fan Yang ${ }^{\mathrm{a}}$, Ling Zhao ${ }^{\mathrm{a}}$, Bin Gao ${ }^{\mathrm{b}, \mathrm{a}}$, Xiaoyun $\mathrm{Xu}^{\mathrm{a}}$, Xinde Cao ${ }^{\mathrm{a}, *}$

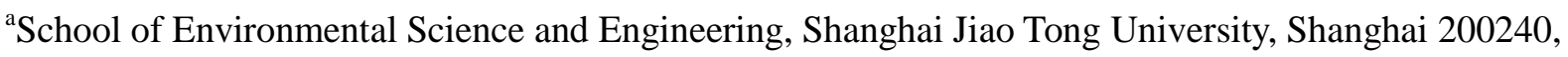 \\ China \\ ${ }^{\mathrm{b}}$ Department of Agricultural and Biological Engineering, University of Florida, Gainesville, Florida \\ 32611, United States \\ * Telephone: +86 21 54743926. Fax: +86 21 54740825. E-mail: xdcao@ sjtu.edu.cn
}

Supporting Information consists of 8 pages, including 3 tables and 3 figures. 


\section{Explanation of the selection of metal chlorides dosage}

In this study, the dosage of metal chlorides addition is designated as $5 \%(\mathrm{w} / \mathrm{w}$, metal $/$ kaolinite), which is within the range of the contents of the available metals in real soils. Take $\mathrm{Ca}$ as an example, the amount of exchangeable $\mathrm{Ca}$ in most soils accounts for about $0.5 \%(\mathrm{w} / \mathrm{w})$ of the soil (Nakamura et al. 2007). It is assumed that the amount of clay accounts for about 10-50\% (w/w) of the soil (Li et al. 2013, Nakamura et al. 2007). Therefore, the ratio of the $\mathrm{Ca} /$ minerals should be in the range of $1-5 \%$. This calculation is also applied to other metals. Therefore, we selected the ratio of metal/kaolinite as $5 \%(\mathrm{w} / \mathrm{w})$.

\section{REFERENCE}

Li, F.; Cao, X.; Zhao, L.; Yang, F.; Wang, J.; Wang, S., Short-term effects of raw rice straw and its derived biochar on greenhouse gas emission in five typical soils in China. Soil Sci Plant Nutr 2013,59, (5), 800-811.

Nakamura, S.; Hiraoka, M.; Matsumoto, E.; Tamura, K.; Higashi, T., Humus composition of Amazonian dark earths in the middle Amazon, Brazil. Soil Science \& Plant Nutrition 2007,53, (3), 229-235. 
Table S1.Selected Properties of the Biochar

\begin{tabular}{llll}
\hline & Item & \multicolumn{1}{c}{ Unit } & Value \\
\hline Basic properties & Yield & $\%$ & 30.5 \\
& $\mathrm{pH}$ & - & 8.22 \\
& $\mathrm{SA}$ & $\mathrm{m}^{2} \mathrm{~g}^{-1}$ & 24.0 \\
& $\mathrm{PV}$ & $\mathrm{cm}^{3} \mathrm{~g}^{-1}$ & 0.321 \\
Organic elements & $\mathrm{Ash}$ & $\mathrm{g} \mathrm{kg}^{-1}$ & 23.0 \\
& & & \\
& $\mathrm{C}$ & $\mathrm{g} \mathrm{kg}^{-1}$ & 880 \\
& $\mathrm{~N}$ & $\mathrm{~g} \mathrm{~kg}^{-1}$ & 3.40 \\
& $\mathrm{H}$ & $\mathrm{g} \mathrm{kg}^{-1}$ & 31.9 \\
& $\mathrm{O}$ & $\mathrm{g} \mathrm{kg}^{-1}$ & 84.7 \\
& & & \\
& $\mathrm{~K}$ & $\mathrm{~g} \mathrm{~kg}^{-1}$ & 5.60 \\
& $\mathrm{Ca}$ & $\mathrm{g} \mathrm{kg}^{-1}$ & 6.06 \\
& $\mathrm{Si}$ & $\mathrm{g} \mathrm{kg}^{-1}$ & 4.43 \\
& $\mathrm{Na}$ & $\mathrm{g} \mathrm{kg}^{-1}$ & 0.745 \\
& $\mathrm{Mg}$ & $\mathrm{g} \mathrm{kg}^{-1}$ & 0.665 \\
& $\mathrm{Al}$ & $\mathrm{g} \mathrm{kg}^{-1}$ & 0.328 \\
& $\mathrm{Fe}$ & $\mathrm{g} \mathrm{kg}^{-1}$ & 0.114 \\
\hline
\end{tabular}

SA, BET- $\mathrm{N}_{2}$ surface area; PV, pore volume 
Table S2.Results of the XPS Analysis for the Relative Atomic Percentage of all Elements of the Original Biochar and the Biochar after 3-month Incubation with Series of Soil Minerals

\begin{tabular}{|c|c|c|c|c|c|c|c|}
\hline & $\mathrm{C} 1 \mathrm{~s}$ & $\mathrm{O} 1 \mathrm{~s}$ & Si $2 p$ & $\mathrm{Cl} 2 \mathrm{p}$ & Fe $2 p$ & $\mathrm{Ca} 2 \mathrm{p}$ & $\mathrm{Al} 2 \mathrm{p}$ \\
\hline Original Biochar & 87.6 & 9.6 & 0.5 & 0.9 & I & 0.8 & 0.7 \\
\hline Incubated Biochar & 78.5 & 18.0 & 0.5 & 1.7 & l & 0.8 & 0.5 \\
\hline Biochar $+\mathrm{AlCl}_{3}$ & 90.9 & 7.9 & 0.2 & 0.9 & I & I & 0.4 \\
\hline Biochar $+\mathrm{CaCl}_{2}$ & 82.7 & 13.6 & 0.4 & 1.4 & l & 2.4 & l \\
\hline Biochar $+\mathrm{FeCl}_{3}$ & 65.8 & 22.6 & l & 5.9 & 5.8 & l & l \\
\hline Biochar+kaolinite & 23.3 & 44.2 & 19.8 & 0.3 & l & 0.7 & 12.3 \\
\hline Biochar $+\mathrm{AlCl}_{3}+$ kaolinite & 23.7 & 48.4 & 16.7 & 0.7 & l & l & 10.5 \\
\hline Biochar $+\mathrm{CaCl}_{2}+$ kaolinite & 36.3 & 38.4 & 14.9 & 0.3 & l & 0.5 & 9.6 \\
\hline Biochar $+\mathrm{FeCl}_{3}+$ kaolinite & 22.1 & 44.8 & 19.9 & 1.0 & 1.0 & l & 11.1 \\
\hline
\end{tabular}

/ below detection limit 
Table S3. Results of the BET-N ${ }_{2}$ Analysis for the Average Pore Diameter of the Biochar after 3-month Incubation with Series of Soil Minerals

\begin{tabular}{lc}
\hline & Average pore diameter (nm) \\
\hline Incubated Biochar & 23.4 \\
Biochar $+\mathrm{AlCl}_{3}$ & 20.2 \\
Biochar $+\mathrm{CaCl}_{2}$ & 20.1 \\
Biochar $+\mathrm{FeCl}_{3}$ & 10.4 \\
Biochar+kaolinite & 17.9 \\
Biochar $+\mathrm{AlCl}_{3}+$ kaolinite & 27.8 \\
Biochar $+\mathrm{CaCl}_{2}+$ kaolinite & 31.8 \\
Biochar $+\mathrm{FeCl}_{3}+$ kaolinite & 25.3 \\
\hline
\end{tabular}



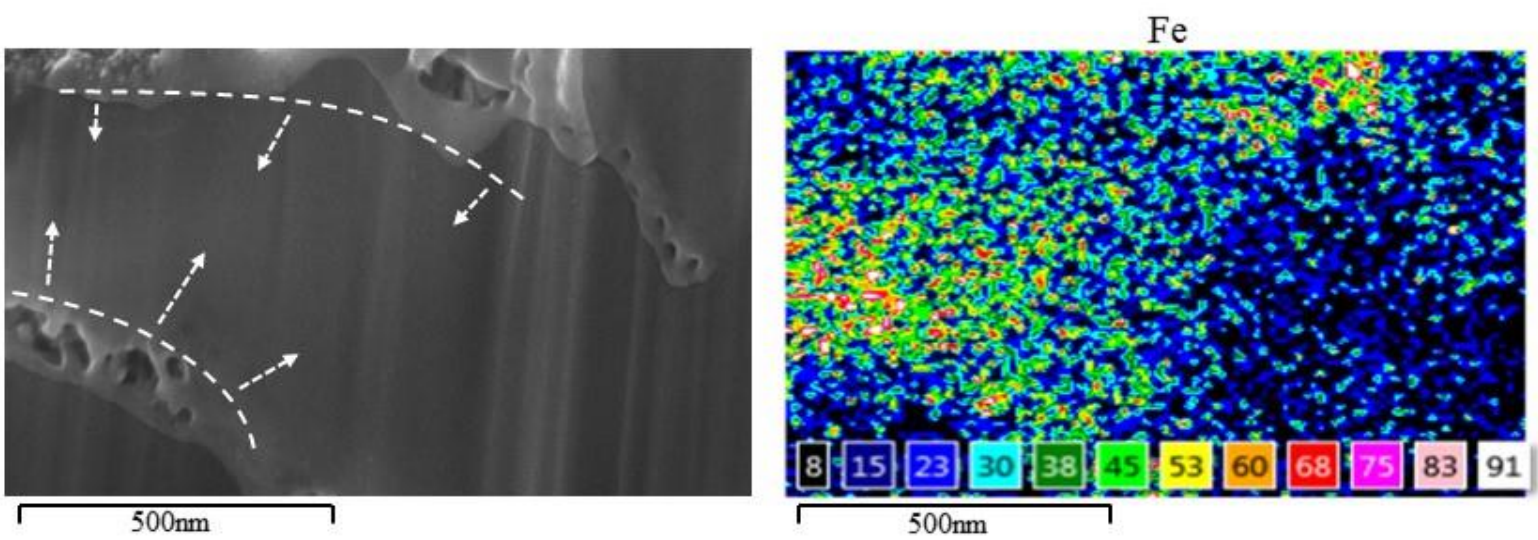

Figure S1.SEM image (left) and elemental mapping (right) of the cross-sectioned biochar following 3-month incubation with kaolinite and $\mathrm{FeCl}_{3}$ (scale bar: $500 \mathrm{~nm}$ ). The dashed lines and arrows in the left SEM image indicate the Fe diffusing towards the biochar interior, which could be confirmed by the color change from the right mapping image. Fe gradient concentrations are relatively indicated by the numbers shown in the different colors. 

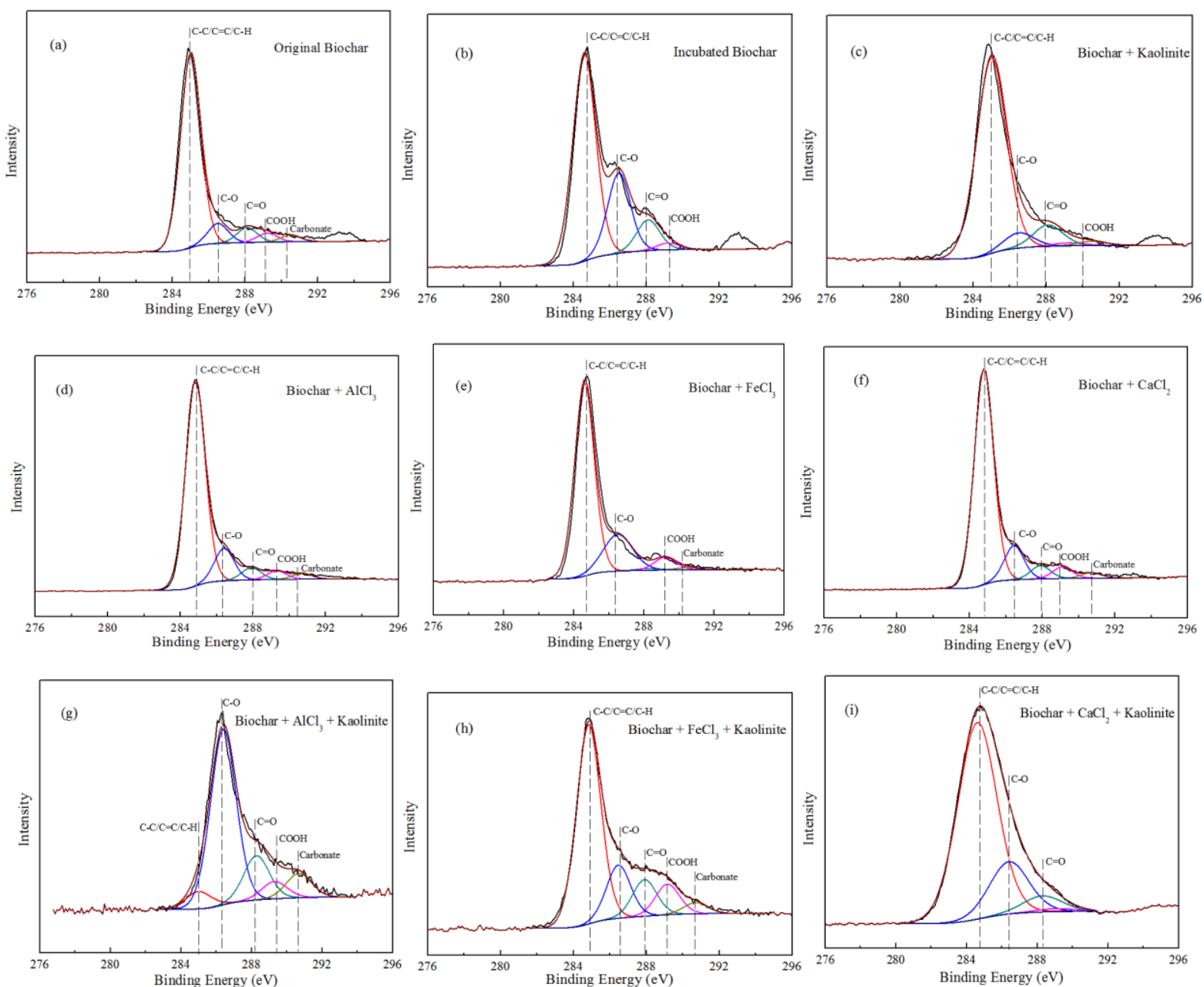

Figure S2.XPS C 1s region scan and peak fitting for the original biochar and the biochar after 3-month incubation with series of soil minerals 

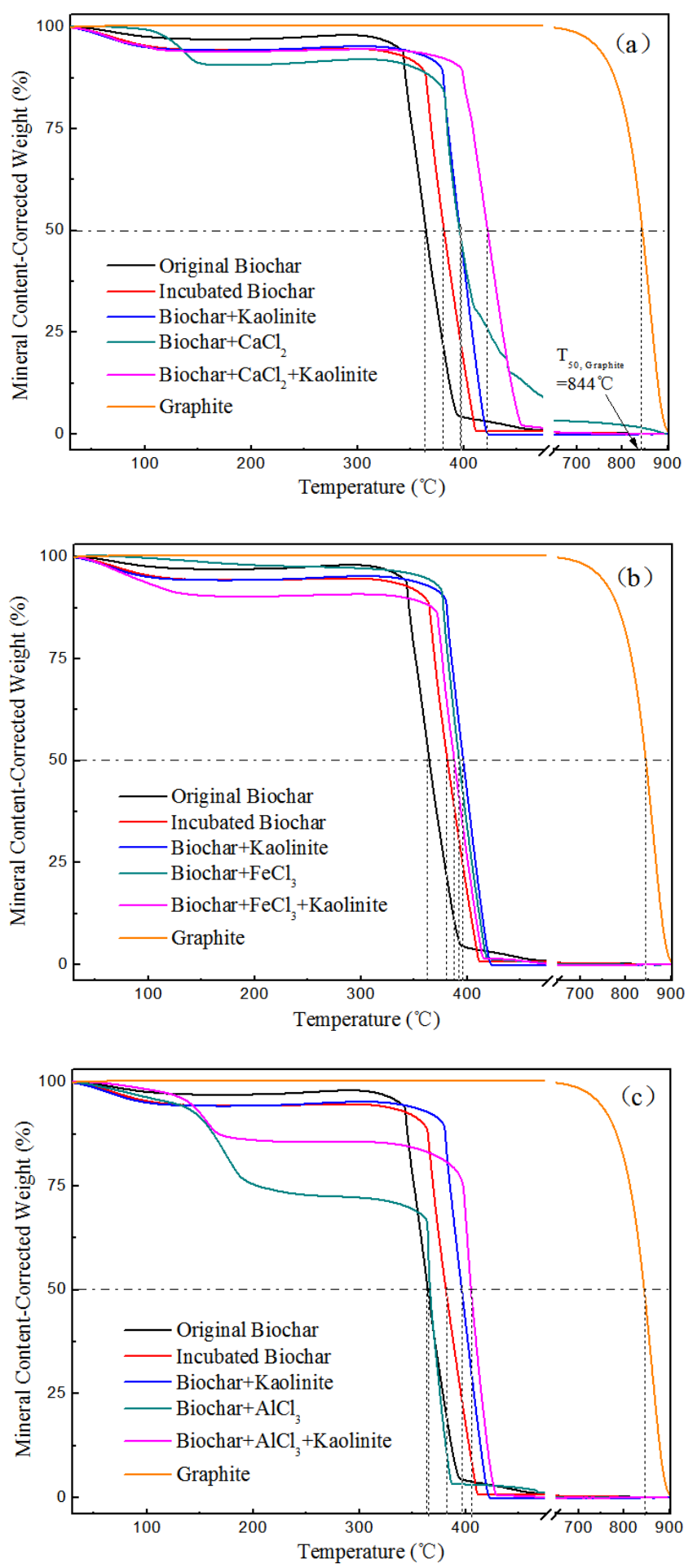

Figure S3. Mineral content-corrected thermo gravimetric patterns of the graphite and the biochar after 3-month incubation with series of soil minerals 